\title{
Efek Ekstrak Air Daun Insulin (Tithonia Diversifolia) pada Status Darah Tikus (Rattus Norvegicus L.) Hiperglikemik
}

\section{Effect of Extract Insulin Leaves (Tithonia Diversifolia) to Blood Status of Hyperglicemic Rats (Rattus Norvegicus L.)}

\author{
Enny Yusuf Wachidah Yuniwarti* dan Silvana Tana \\ Departemen Biologi, Fakultas Sains dan Matematika, Universitas Diponegoro \\ Jl. Prof. Soedarto SH, Tembalang, Semarang \\ *Email: enny_yusuf@yahoo.co.id
}

Diterima 26 Desember 2018 / Disetujui 28 Januari 2019

\begin{abstract}
ABSTRAK
Penelitian ini bertujuan untuk melakukan analisis efek ekstrak air daun insulin terhadap status darah tikus hiperglikemik. Kondisi hiperglikemik akan meningkatkan jumlah radikal bebas yang dapat merusak struktur membran eritrosit sehingga menurunkan jumlah eritrosit, persentase hematokrit dan kadar hemoglobin. Penelitian ini menggunakan 16 ekor tikus Wistar jantan yang dikelompokkan dalam 4 kelompok perlakuan yaitu P0 merupakan kelompok kontrol, P1 kelompok tikus hiperglikemik yang diberi glibenklamid $2 \mathrm{mg} / \mathrm{BB}$, P2 dan P3 kelompok tikus hiperglikemi yang diberi ekstrak air daun insulin $30 \mathrm{mg} / \mathrm{BB} /$ hari dan 60 $\mathrm{mg} / \mathrm{BB} / \mathrm{hari}$. Desain penelitian yang digunakan adalah Rancangan Acak Lengkap dengan 4 perlakuan dan 4 ulangan.Pakan dan minum diberikan ad libitum selama 4 minggu. Hasil penelitian menunjukkan bahwa jumlah eritrosit tidak berbeda nyata pada semua perlakuan, begitu pula persentase hematokrit dan kadar hemoglobin tidak berbeda nyata antar kelompok perlakuan. Kesimpulan dari penelitian ini adalah bahwa ekstrak air daun insulin mampu memperbaiki status darah tikus hiperglikemi setara dengan glibenklamid.
\end{abstract}

Kata kunci: eritrosit, hemoglobin, hematokrit, daun insulin, tikus hiperglikemi

\section{ABSTRACT}

This study aims to analyze the effect of insulin leaf water extract on the blood status of hyperglycemic rats. Hyperglycemic conditions will increase the number of free radicals that can damage the structure of erythrocyte membranes thereby reducing the number of erythrocytes, the percentage of hematocrit and hemoglobin levels. This study used 16 male Wistar rats grouped in 4 treatment groups namely P0 was the control group, $\mathrm{P} 1$ group hyperglycemic rat given glibenclamide $2 \mathrm{mg} / \mathrm{BB}, \mathrm{P} 2$ and $\mathrm{P} 3$ groups of hyperglycemic mice given extract insulin leaf water $30 \mathrm{mg} / \mathrm{BW} /$ day and $60 \mathrm{mg} / \mathrm{BW} /$ day. The research design used was a completely randomized design with 4 treatments and 4 replications. Feed and drink were given ad libitum for 4 weeks. The results showed that the number of erythrocytes was not significantly different in all treatments, so as the percentage of hematocrit and hemoglobin levels were not significantly different between all groups. The conclusion of this study was that insulin leaf water extract can improve the blood status of hyperglycemic mice equivalent to glibenclamide.

Keywords: erythrocytes, hemoglobin, hematocrit, leaf insulin, hyperglycemic rat

\section{PENDAHULUAN}

Status darah merupakan faktor penting dalam menentukan derajad kesehatan manusia melalui hewan model. Salah satu cara evaluasi status darah adalah dengan menentukan julah eritrosit, persentase hematokrit dan kadar hemoglobin (Said dan Abiola, 2014). Jumlah sel darah merupakan indikator terhadap produksi dan kualitas sel darah. Jumlah sel darah yang kurang dari normal akan menyebabkan hewan mudah terkena penyakit, sehingga jumlah sel darah dapat digunakan untuk diagnosis, pengobatan dan prognosis suatu penyakit (Li et al., 2013). Fungsi 
eritrosit secara umum berkaitan dengan fungsi hemoglobin yaitu berperan dalam pertukaran gas dan distribusi oksigen ke dalam sel, yang diperlukan oleh sel untuk proses metabolisme. Dua dekade terakhir, beberapa penelitian menunjukkan bahwa eritrosit berperan pula dalam fungsi kekebalan tubuh secara menyeluruh, yaitu mulai dari identifikasi, adhesi dan pembunuhan patogen sehingga mampu meregulasi sistem kekebalan tubuh (Tian et al., 2013).

Kondisi hiperglikemik akan menghasilkan radikal bebas yang selanjutnya radikal bebas dapat menyebabkan gangguan fungsi seluler dan kerusakan oksidatif pada membran serta meningkatkan kerentanan terhadap peroksidasi lipid. Status antioksidan total serum berkurang pada diabetes tipe I, sedangkan sel darah merah dan sel lain dari hewan diabetes meningkatkan konsentrasi peroksidasi lipid dan menurunkan konsentrasi glutathion (Andallua dan Varadacharyulub, 2003).

Komplikasi yang timbul dari kondisi hiperglikemik seperti nefropati, retinopati, dan penyakit makrovaskular berhubungan dengan anemia. Eriptosis, istilah yang digunakan untuk apoptosis eritrosit, dipicu oleh syok osmotik, stres oksidatif, atau berkurangnya energi. Eriptosis juga ditandai dengan penyusutan sel, pembengkakan membran, membran fosfolipid, dan phosphatidylserin bergeser dari membran dalam ke luar dari eritrosit. Anemia pada kondisi hiperglikemik didasari oleh eriptosis yang terkait dengan cedera mikrovaskuler, adhesi endotel dan peningkatan agregasi eritrosit (Firat et al., 2012).

Upaya pemulihan kondisi hiperglikemi secara tradisional dapat dilakukan dengan mengkonsumsi daun atau tanaman yang bersifat antidiabetik. Salah satu bahan yang bersifat antidiabetik terdapat dalam daun insulin. Daun insulin (Tithonia diversifolia) mengandung senyawa flavonoid, alkaloid, terpenoid, saponin, tanin, polifenol, seskuiterpen, asam klorogenik dan turunan asam klorat yang bersifat antidiabetik (Passoni et al., 2013). Pemulihan kondisi hiperglikemik dapat mengurangi penurunan status darah, sehingga penelitian ini bertujuan untuk mengetahui apakah ekstrak air daun insulin mampu menghambat kerusakan sel eitrosit, hemoglobin dan nilai hematokrit.

\section{METODE PENELITIAN}

Penelitian ini menggunakan tikus putih (Rattus norvegicus) hiperglikemik, jantan berumur 2 bulan dengan berat badan sekitar $200 \mathrm{~g}$ sebanyak 20 ekor yang dibagi dalam 4 perlakuan dengan 4 ulangan. Perlakuan 0 adalah perlakuan kontrol, perlakuan 1 adalah kelompok tikus hiperglikemik yang diberi glibenklamid $2 \mathrm{mg} / \mathrm{BB}$ tikus, perlakuan 2 adalah kelompok tikus hiperglikemik yang diberi 0,2 ml larutan stok 1, dan perlakuan 3 adalah kelompok tikus hiperglikemik yang diberi 0,2 $\mathrm{ml}$ larutan stok 2,

Persiapan pembuatan larutan stok daun insulin dengan cara menimbang $1000 \mathrm{~g}$ daun insulin yang sudah dihaluskan dan di kering anginkan kemudian dimaserasi dengan 2 liter akuades selama 24 jam. Hasil maserasi disaring dan diuapkan sehingga berbentuk pasta. Pasta yang didapat diambil $30 \mathrm{mg}$ dan $60 \mathrm{mg}$ yang dilarutkan dalam $3 \mathrm{ml}$ akuades sebagai larutan stok 1 dan larutan stok 2.

Peubah yang diamati adalah jumlah eritrosit dan kadar hemoglobin dan nilai hematokrit. Darah dikoleksi pada akhir perlakuan, diambil dari jantung setelah tikus dibius dengan kloroform, dan ditampung pada tabung $2 \mathrm{ml}$ untuk penentuan jumlah eritrosit dan kadar hemoglobin dan nilai hematokrit. Perlakuan selama 4 minggu dan pada akhir minggu ke 4 dilakukan koleksi sampel untuk pengambilan data. Data yang didapat selanjutnya dianalisis dengan ANOVA.

\section{HASIL DAN PEMB AHASAN}

Berdasarkan hasil analisis data jumlah eritrosit tidak menunjukkan adanya beda nyata antar perlakuan begitu pula kadar hemoglobin dan nilai hematokrit tidak berbeda nyata antar kelompok perlakuan, seperti nampak pada Tabel 1. Jumlah eritrosit pada semua perlakuan tikus hiperglikemik tidak berbeda nyata dengan kontrol, baik yang diberi ekstrak air daun insulin 30 $\mathrm{mg} / \mathrm{BB} / \mathrm{hari} 60 \mathrm{mg} / \mathrm{BB} / \mathrm{hari}$ maupun perlakuan dengan glibenklamid. Glibenklamid merupakan 
sulfonilurea oral yaitu suatu agen hipoglikemik melalui peningkatan sekresi insulin dari pankreas. Reseptor sulfonilurea pada pemukaan membran sel akan berinteraksi dengan sel beta atau mengganggu saluran potassium ATP-sensitif pada sel $\beta$ pankreas, sehingga terjadi peningkatan sekresi insulin. Glibenklamid juga meningkatkan sensitivitas reseptor insulin yang ada, sehingga digunakan sebagai pengobatan oral dalam manajemen hiperglikemik (Papich, 2016).

Tabel 1. Hasil ANOVA rata-rata jumlah eritrosit, nilai hematokrit dan kadar hemoglobin tikus potih (Rattus norvegicus) jantan hiperglikemik setelah pemberian ekstrak air daun insulin (Tithonia diversifolia)

\begin{tabular}{lllll}
\hline & P0 & P1 & P2 & P3 \\
\hline Jumlah eritrosit (juta/ml) & $4,95^{\mathrm{a}} \pm 0,13$ & $4,90^{\mathrm{a}} \pm 0,46$ & $4,78 \mathrm{a} \pm 0,24$ & $4,93 \mathrm{a} \pm 0,22$ \\
Kadar hemoglobin (gram/dl) & $14,83^{\mathrm{a}} \pm 0,25$ & $14,03^{\mathrm{a}} \pm 0,69$ & $14,58^{\mathrm{a}} \pm 0,66$ & $14,88^{\mathrm{a}} \pm 0,66$ \\
Nilai hematokrit (\%) & $44,50^{\mathrm{a}} \pm 1,3$ & $41,75^{\mathrm{a}} \pm 2,22$ & $43,25^{\mathrm{a}} \pm 2,26$ & $44,25^{\mathrm{a}} \pm 2,22$ \\
\hline
\end{tabular}

Keterangan: superscript yang sama pada baris yang sama menunjukkan tidak berbeda nyata.

Penelitian ini menggunakan glibenklamid sebagai pembanding sehingga tidak adanya perbedaan yang nyata antara perlakuan ekstrak air daun insulin, baik pada dosis $30 \mathrm{mg}$ dan $60 \mathrm{mg}$ dengan perlakuan glibenklamid, diduga karena ekstrak air daun insulin tersebut mampu menangkal radikal bebas yang dihasilkan pada kondisi hiperglikemik sehingga tidak terjadi kerusakan eritrosit lebih lanjut. Komponen yang terkandung dalam daun insulin adalah flavonoid dan seskuiterpen lakton yang berperan sebagai antidiabetik (Sasmita dkk., 2017). Flavonoid bekerja melalui pengikatan radikal bebas sehingga menstabilkan kompleks transkripsi gen untuk regenerasi sel $\beta$ pankreas (Qi et al., 2010). Flavonoid juga berperan menekan apoptosis sel $\beta$ pankreas, memperbaiki sensitivitas reseptor insulin sehingga mampu meningkatkan absorpsi glukosa (Sasmita dkk., 2017). Seskuiterpen lakton berperan sebagai inhibitor aktivasi nuclear faktor kappa B (Heinrich et al., 1998). Nuclear faktor kappa B yang meningkat akibat stimulasi peningkatan kadar glukosa dalam darah akan menyebabkan peningkatan resistesi insulin, sehingga penghambatan aktivasi nuklear faktor kappa B oleh sesquiterpen akan meningkatkan sensitivitas insulin sehingga mempermudah glukosa masuk ke dalam sel dan mengurangi efek hiperglikemik (Kumar et al., 2004).

Beberapa penelitian juga menunjukkan bahwa eritrosit dengan hemoglobin berperan penting dalam pertukaran gas dan distribusi oksigen ke dalam sel. Eritrosit juga berperan dalam sistem kekebalan tubuh secara menyeluruh (Tian et al., 2013). Jumlah eritrosit merupakan indikator produksi dan kualitas sel eritrosit, sehingga jumlah sel eritrosit digunakan untuk diagnosis, pengobatan dan prognosis. Secara klinis, penurunan jumlah eritrosit akan berakibat pada penurunan hemoglobin dan menyebabkan terjadinya anemia (Li et al., 2013). Pernyataan tersebut sesuai dengan hasil penelitian yang menunjukkan tidak ada beda nyata pada kadar hemoglobin antar semua perlakuan, karena tidak terjadinya perbedaan yang nyata pada jumlah eritrosit berkorelasi dengan kadar hemoglobin.

Hasil penelitian pada nilai hematokrit menunjukkan tidak berbeda nyata pada semua perlakuan, hal ini diduga terkait dengan jumlah eritrosit yang tidak berbeda nyata antar perlakuan. Hematokrit merupakan persentase volume darah yang terisi oleh sel darah merah. Nilai hematokrit pada penderita diabetes dapat mengalami peningkatan atau penurunan. Kadar glukosa darah yang tinggi dapat menyebabkan keluarnya air dari jaringan, sehingga terjadi dehidrasi. Dehidrasi merupakan salah satu faktor yang mempengaruhi peningkatan nilai hematokrit (Safitri dkk., 2017).

Eritrosit mampu mengekspresikan nitrit oksida yang berperan dalam menghambat replikasi virus (Stephenson, 2003). Hemoglobin akan mengurangi nitrit untuk diubah menjadi nitrit oksida sehingga eritrosit- $\mathrm{Hb}$ dianggap sebagai sumber nitrit oksida sintase yang menstimulasi pembentukan nitrit oksida. Nitrit oksida merupakan molekul signaling yang sangat penting 
(Petra et al., 2006), dan berperan sebagai antioksidan melalui deaktivasi radikal bebas (Richard et al., 1998). Jumlah eritrosit pada perlakuan ekstrak air daun insulin yang tidak berbeda nyata dengan perlakuan glibenklamid, karena adanya antioksidan yang terkandung daun insulin, juga kemampuan eritrosit dalam deaktivasi radikal bebas.

\section{KESIMPULAN}

Kesimpulan dari penelitian ini adalah bahwa ekstrak air daun insulin mampu memperbaiki status darah tikus hiperglikemik setara dengan glibenklamid.

\section{DAFTAR PUSTAKA}

Andallua B. and N.Ch. Varadacharyulub. Antioxidant role of mulberry (Morus indica L. cv. Anantha) leaves in streptozotocin-diabetic rats. Clinica Chimica Acta 338 (2003) 3-10

Frrat U.,1 Savas, Kaya, Abdullah C, H B"uy"ukbayram,1 O G"okalp,M S Dal, and M.N Tamer. Increased Caspase-3 Immunoreactivity of Erythrocytes in STZ Diabetic Rats. Experimental Diabetes Research Volume 2012, Article ID 316384, 4 pages

Heinrich M., Robles M., West J.E., De Montellano B.R., and E. Rodriguez. 1990. Ethnopharmacology of Mexican Asteraceae (Compositae). Annual Review of Pharmacology Toxicology 38:539-565.

Kumar A., Takada Y., Boriek A.M., and.B. B. Aggarwal., Nuclear factor-kB: its role in health and disease. J Mol Med (2004) 82:434-448

Li C., Yulong Dong, Haifeng Hou, Qian Li, Ruihua Zhang, Ruiling Qin, Zhonghao Li, Yongzhan Bao and Wanyu Shi. 2013. Effects of traditional Chinese herbal medicines on blood cell count and immunity in chickens. African Journal of Pharmacy and Pharmacology. Vol. 7(29), pp. 2081-2086, 2013. DOI 10.5897/ AJPP2013.3460 ISSN 1996-0816
Papich M.G, Glyburide. Saunders Handbook of Veterinary Drugs (Fourth Edition), 2016

Passoni F.D Oliveira R.B., Aparecida D. Chagas-Paula Leonardo Gobbo-Neto and F.B Da Costa. Repeated-dose toxicological studies of Tithonia diversifolia (Hemsl.) A. gray and identification of the toxic compounds. Journal of Ethnopharmacology. Volume 147, Issue 2, 20 May 2013, Pages 389-394

Petra Kleinbongard, Rainer Schulz, Tienush Rassaf, Thomas Lauer, André Dejam, Thomas Jax, Intan Kumara, Putrika Gharini, Svetlana Kabanova, Burcin Özüyaman, Hans-Georg Schnürch, Axel Gödecke, Artur-A. Weber, Mirko Robenek, Horst Robenek, Wilhelm Bloch, Peter Rösen, and Malte Kelm. 2006. Red Blood Cell Express a Functional Endothelial Nitric Oxide Synthase. Blood: 107 (7).

Richards RS, Roberts TK, McGregor NR, Dunstan RH, Butt HL: The role of erythrocytes in the inactivation of free radicals. 1998. The Role Of Erythrocytes In The Inactivation Of Free Radicals. Med Hypotheses 1998, 50 (5):363-367

Said N. and O. Abiola. Haematological profile shows that Inbred Sprague Dawley rats have exceptional promise for use in biomedical and pharmacological studies. Asian Journal of Biomedical and Pharmaceutical Sciences; 4 (37) 2014, 3337

Safitri S. Razak A. dan R. Sumarmin. Pengaruh Varietas Beras Puth Sumatera Barat Terhadap Nilai Hematokrit Darah Mencit (Mus Musculus L. Swiss Webster) Jantan. Bioscience Vol 1, No 1 (2017)

Sasmita F.W., Susetyorini E., dan Y. Pantiwati.. Efek Ekstrak Daun Kembang Bulan (Tithonia diversifolia) Terhadap Kadar Glukosa Darah Tikus Wistar Yang Diinduksi Alloxan. Biosfera 34 (1): 22-31 (2017)

Stephenson, I., Wood, J.M., Nicholson, K.G. and Zambon, M.C. (2003), Sialic Acid Receptor Specificity on Erythrocytes 
Affects Detection Of Antibody To Avian Influenza Haemagglutinin. J. Med. Virol., 70: 391-398. doi: 10.1002/jmv.10408

Tian W.X., N. Sun, G.B. Ning, D.J. Zhang, J. Feng, T.X. Lv, Y. Wang, H.M. Wang, X.H. Wang and F. Li. 2013. Effects of
Gallid Herpesvirus 2 Marek's Disease Challenge Virus and Attenuated Vaccine Virus CVI988/Rispens on Immune Adhesion of Erythrocytes of Chickens. International Journal of Poultry Science 12 (4): 217-223, 2013. ISSN 1682-8356 